Extended Abstract

\title{
Dialectic of Capitalism
}

\author{
Asher Jospe \\ Tel Aviv University, Israel, Tel Aviv \\ Asherj@netvision.net.il \\ Tel.: +972-54-661-7733; Fax: +972-9-834-7688
}

Accepted:

\section{Introduction}

Karl Marx has predicted in his Communist Manifest the self-destruction of Capitalism. Although he himself has admired the achievements of bourgeoisie Capitalism, he at the same time predicted that the inherent internal contradictions of Capitalism will eventually bring it down.

Marx made this prediction around 1860, and since then, more than 150 years have passed. During this period Capitalism has suffered a few situations of massive crisis and indeed came close to selfdestruct. Nonetheless, it has survived worldwide wars; major technological changes and massive shifts in fundamental paradigms of social, political and culture.

Furthermore, Capitalism was not brought down by any emancipatory agent, as predicted by Marx, neither has it brought about its own demise by self-destructing. It has indeed continued to be a powerful economic and political force, spreading its ideology to numerous countries, while using NeoLiberal ideology and ICT technology, and thus implementing globalization as indeed, has been predicted by Karl Marx.

\section{Methods}

Capitalism, as we know it and as articulated by Karl Marx, is a political and economic production structure under which societies in the western world operate to produce goods and services. It is an based on free market ideology on one hand, and some level of state involvement on the other hand. Its emphasis is on Innovation and entrepreneurship. It is political in the sense that the balance between state and markets is determined by politician bodies and people. Its most striking characteristic is employment of workers who produce goods which are sold on the market for a profit, where the profits belong to the business owners. The forces of production together with the production relations, 
produce surplus value and thus profits to the owners. Capitalism is organized around businesses which produce products and services, investors, employers, employees, and state institutions such as the Federal Reserve. It is a "Complex System" as the term is defined in Biology in multi- cell organisms. It is the contention of this paper that its evolution approximates the rule of natural selection, namely: "The survival of the fittest". The system was able to protect itself over its 200 years of existence by adapting with each crisis to the new demands of reality (such as the level of state intervention) and recently, by adapting a modus operandi which unquestionably, require massive state intervention to cope with the crisis. Examples are the New Deal in 1932 and the creation of the welfare state in Europe, as well as the massive QE program by the state in the 2007-2009 near melt-down calamity.

Technology has a very substantial role in the development, evolution and progress of the Capitalistic system. As technology changes over time, we are witnessing a phenomenon which has no precedence. Capitalism adopts the most current available technology and uses it to improve productivity; to accelerate production; to shorten the time to market and to reduce dependability on human (worker) involvement. With the advance of ICT technology, Capitalism was able to effectively implement its neo-liberal ideology. Capitalism thus uses technology to produce more goods and services more efficiently (and by doing so it controls the "Supply Management"), and on the other hand it uses the same technology to execute "Demand Management" methods, thus, assuring that there will be enough clients to consume the products and services it produces. Examples are the use of the Smartphone to make consumption as easy and as available as possible, and the use of the Internet for faster movement of capital, goods and information required for the multi-site, global production of goods and services.

On one hand, the technology makes the "Complex System" operate faster. The movement of capital, human resources, and information is now at the fastest pace ever in the history of mankind and it continues to accelerate. This challenges the "Complex System" and may bring it down and destroy it as the speed increases to levels which are intolerable to the system itself and to the consumers. The speed with which the "Complex System" now operates put a tremendous stress on itself, and with stress it challenges its weak points. The higher the speed, the more bugs are bound to appear, as in any system which is being strained to its limit. The consumers are an absolute requirement of the Capitalist system for it to survive. On the other hand, the same technology provides Capitalism with tools to track, monitor and collect very private information about the consumer. Its privacy is heavily compromised by the Capitalistic system. For Capitalism this ability guarantees targeting is much more efficient and thus the system is more profitable. Capitalism continuously collects the data about the consumer behavior, and thus has very effective information about consumer tastes, wants and desires. It thus provides goods and services which meet consumer preferences everywhere in the world in the most effective way. For the state, this unprecedented ability to track and monitor user behavior, provides tools to identify critical forces and to control these forces at their very beginning, thus enforcing the "One Dimensionality" of the society, as articulated by Herbert Marcuse in his book. It appears that Capitalism has provided the Subject with a tradeoff which never existed before: "Sacrifice Privacy" in order to gain "Always on Connectivity" 


\section{Results and Discussion}

It is the thesis of this paper, that Capitalism has developed over the years the ability to adapt and to mutate into different modes of Capitalism, while retaining its two most fundamental core values, namely that of maximizing profits and that of utilizing private work to generate this profit, namely retaining the core concept of oppressors and oppressed. This ability to mutate and adapt has been the key to the survival of Capitalism. Furthermore, Capitalism has strengthened and became a more powerful entity as it put to work the most modern network media in manipulating the subject and shaping the subjects' material needs. This system is moving forward as a Creative Destruction force. It destroys the previous version of itself, while retaining the core values and then proceeds to manifest itself as a "New Improved" system, more powerful and more efficient Capitalism.

\section{Conclusions}

To conclude, I need to address the question of whether Capitalism can ever be destroyed as a system. The question at hand is thus whether there are conditions under which the adaptability and mutability of Capitalism will not be sufficient and its ability to bend over shall not be sufficient to prevent its self-destruction.

As stated above, Capitalism has two components which govern it as a Complex System: Political and Economic. In the political arm which based on politicians who make the decisions, where the weakest point of the system can be observed. This is where Capitalism could tilt the crisis into an irreversible global melt down and thus bring about its own massive destruction. This is certainly the weak link which because it is predicated on human behavior, cannot be predicted with certainty and it is here where the true possibility of self- destruction lies. Even assuming that mankind usually strives to better its conditions of existence, this assumption is in strong conflict with dogmatic, free market, non- state intervention paradigm. As such, if the dogmatic forces prevail, it is very likely to lead to a total destruction of Capitalism as we know it today. In the potential clash between the Capitalist dogmatic fundamentalist forces and the forces required to save Capitalism from its own destruction (by sacrificing the very ideology of Free Market, no state intervention of Capitalism), there lies the possibility of the self-destruction of Capitalism, as it entails politicians making decisions which defy their long standing dogmatic thinking.

\section{References and Notes}

1. Marx, K.; The Communist Manifesto, 1840.

2. Marcuse, H.; One-Dimensional Man, 1960.

3. Morozov, E.; The Net Delusion, In Public Affairs USA, 2011.

4. Hassan, R.; Media, Politics and the network society, McGraw Hill House, Berkshire, UK, 2004.

(C) 2015 by the authors; licensee MDPI and ISIS. This abstract is distributed under the terms and conditions of the Creative Commons Attribution license. 